\title{
The Role of Interpersonal EFL Teacher Behaviour in Enhancing Saudi Students' Learning
}

\author{
Nada Rashed AlDhafiri ${ }^{1}$ \\ ${ }^{1}$ Department of Education, University of Exeter, Exeter, UK. \\ Correspondence: Nada Rashed AlDhafiri, Department of Education, University of Exeter, Heavitree Road, Exeter, \\ EX12LU, UK. E-mail: Nrsa201@exeter.ac.uk; Nadaaldhafiry@yahoo.com
}

Received: October 23, 2014 Accepted: December 23, 2014 Online Published: January 3, 2015

doi:10.5430/ijelt.v2n1p47 URL: http://dx.doi.org/10.5430/ijelt.v2n1p47

\begin{abstract}
This study investigated relationships between students' perceptions of their teachers' interpersonal behaviour and their learning outcomes in English as a Foreign Language (EFL). This study looked at how teacher-student interpersonal behaviour leads to better academic performance. 200 female participants took part (16-18 years old) from two secondary/high schools in Saudi Arabia. An adapted version of the Questionnaire on Teacher Interaction (QTI) was utilised and covered two independent dimensions called Influence (teacher dominance vs. submission) and Proximity (teacher cooperation vs. opposition). Using descriptive statistics and Pearson's Chi-Square statistics the results showed the majority of the participants perceived their EFL teachers as good leaders and most of the students believed that teachers listened to them. In addition, a positive opinion was found about their teachers suggesting good academic performance in these schools. The participants were motivated to learn English either to seek further education, enhance knowledge travel, or out of interest. Finally, the results showed that most of the students who worked cooperatively are aware of their competency levels in EFL classes. The Pearson Chi Square test showed that student level of competency and the teacher profile are dependent on each other. This implies that the teacher can impact student performance and learning. Also the Chi Square tests showed that the course structure does not affect the students' competency in English. Overall the study highlights the importance of communication to create interpersonal relationships that facilitate collaboration in the classroom. Besides, this study uncovered some critical issues problems in EFL teaching in Saudi Arabia such as lack of training for teachers and lack of communication in the class.
\end{abstract}

Keywords: EFL teachers, EFL students, interpersonal behaviour, learning outcomes

\section{Introduction}

It is generally argued that teacher-student interpersonal behaviour is a key factor when teaching and learning are concerned and that it has the potential to impact the learning environment in any country (e.g. Brok, Brekelmans, Tartwijk, \& Wubbels, 2005; Telli, den Brok, \& Cakiroglu, 2007; Yu \& Zhu , 2011). For example, Doyle (1986) stressed the importance of teacher interpersonal behaviour in relation to classroom management. It has also been shown that positive teacher-student interpersonal relationships provide a strong platform to ensure that students are engaged in the learning process (Brekelmans et al., 2000; Wubbels \& Levy, 1993). Accumulating evidence confirms a relationship between teacher-student interpersonal behaviour and the attitudes of students towards the subject, motivational level and academic achievement (Brekelmans, den Brok, van Tartwijk, \& Wubbels, 2005; den Brok, 2001; den Brok, Brekelmans, \& Wubbels, 2004). These effects were found regardless of the nature of the subject taught.

The learning process has been described as heavily dependent on how students perceive, interpret and process information within the educational setting (Shuell, 1996). Hence, from an empirical perspective it is important that research focuses on the perception of students. As such, Wei, den Brok and Zhou (2009) supported the idea that research should carefully consider student perceptions in an endeavour to have a good understanding of the learning environment, in addition to examining its impact on learning outcomes. Several studies have successfully assessed the learning environment from the perspective of the student (e.g., Fisher, Waldrip \& Den Brok, 2005; Fraser \& 
Walberg, 2005; Kiany \& Shayestefar, 2011; Levy, Den Brok, Wubbels \& Brekelmans, 2003). This is despite some criticisms levelled against the reliance on student perspective with regards to its potential flawed nature pertaining to influencing factors such as teacher popularity, grading leniency (Aleamoni, 1999; Greenwald, 1997) or even the characteristics of the students themselves (Aleamoni, 1999). Several studies have investigated the variables that have the potential to affect student perception, in order to shed light on this issue. For example, Levy, den Brok, Wubbels and Brekelmans (2003) found that female students at both primary and secondary levels were more likely than their male counterparts to view their teachers as being dominant. A clear relationship has also been found between the ethnicity of the student and their perceptions of teacher communication patterns (Den Brok \& Levy, 2005). For example, American Asian students perceived a less dominant pattern than African American students, Hispanic or Caucasian background students (Den Brok, Wubbels \& Brekelmans, 2003). Teacher experience and ethnicity were also reported as mediating factors when the perspective of the student was investigated. However, the above authors noted that as far as the association between students' achievement and their perception of teacher behaviour is concerned, this has been inconclusive so far.

Shulman and Tamir (1972) suggested that both cognitive and affective outcomes of learning are as important as the other. In the context of student-teacher interpersonal relationships there are studies which have investigated the affective dimensions separately from the instrumental ones (e.g., Birch \& Ladd, 1998; Rowan, Chiang, \& Miller, 1997) but Crosnoe, Johnson and Elder (2004) suggested that a more holistic approach would be to acknowledge an association between both the affective (e.g., students' motivation) and instrumental elements (e.g., students' academic achievement). In fact, it has been previously documented that students' perceptions of teacher interpersonal behaviour influenced their level of motivation and their learning outcomes across all different subjects (den Brok et al., 2004). For example, a study conducted in Turkey also reported a strong positive influence of teacher interpersonal behaviour on the academic achievement of students learning mathematics (Gorgen \& Tahta, 2005). Furthermore, from a cross-cultural viewpoint, research has shown that teacher characteristics such as dominance and cooperativeness are positively correlated with students' affective outcomes in various countries such as Netherlands (Brekelmans, Wubbels, \& Creton, 1990; den Brok, 2001; den Brok, Brekelmans \& Wubbels, 2004), Australia (Henderson, 1995; Rawnsley, 1997), Singapore (Goh \& Fraser, 1998), Korea (Kim, Fisher, \& Fraser, 2000) and Brunei (den Brok, Fisher, \& Scott, 2005; Riah \& Fraser, 1998). Research by den Brok (2001) on EFL teachers found that interpersonal behaviour was mainly related to affective student outcomes such as pleasure, relevance, confidence and effort. Teacher proximity was also found to have a positive strong effect on learning outcomes. Thus, a more holistic approach is necessary in order to examine these factors all together.

Fisher, Waldrip and Den Brok (2005) reiterate that cultural issues are important in classroom teaching and learning which are mediated by the cultural views of the students. Based on their research, different cultural backgrounds of teachers have been found in some cases to lead to conflicts arising from the expectations of students that are incongruent to that of the teacher. Therefore, the challenge for the teacher is to stimulate learning and ensure that the student is not alienated from society, knowledge, beliefs and values. den Brok (2001) has found strong associations between interpersonal behaviour and teacher clarity while Brekelmans, Sleegers and Fraser (2000) stressed the importance of activating instructions and emphasising student learning and student centeredness. These studies showed that teachers who displayed a high level of interpersonal closeness (proximity) were more likely to have students sharing the view that they were being treated fairly and hence were keener to engage in collaborative activities. Conversely, the students of teachers that were perceived low on proximity felt that they were not treated fairly and were thus less motivated to participate in the learning process. As far as teacher influence is concerned, the directive-authoritative-tolerant and tolerant-authoritative types represent the most common teacher student interactions and usually offer an activity based learning environment that is positively correlated with the students' engagement and motivation in classrooms (Opdenakker et al., 2012).

With regards to second language acquisition, research has shown that motivation plays a determining role (Moskovsky \& Alrabai, 2009). Rao (2005) stressed the importance of initiating various teaching strategies in Saudi Arabia with an aim to boost the motivational level of Saudi EFL learners. However, according to Al Hazmi (2003), EFL teacher preparation programs in Saudi Arabia are generally non-systematic and do not meet the needs of the students. Since untrained teachers often end up teaching English as a second language in order to meet the increasing demand for learning English, the quality of teaching as well as learning are both undermined. The author also highlighted that consequently, the Ministry of Education in Saudi Arabia has started to recruit non-Saudi English teachers to meet the high demand for EFL courses. Additionally, it has been argued that Saudi EFL learners appear to possess a considerable amount of an in-built 'dormant' store of motivation. Under favourable conditions, this 
motivation could be successfully exploited to improve academic achievement (Moskovsky \& Alrabai, 2009, p.7). It is worth noting that the importance of learning English in the kingdom of Saudi Arabia has been increasingly recognised as a "lingua franca; window on the wall" and is now a top priority for its educational planning (ur Rahman, 2011, p. 381) and there is a equal need for the Saudi government to support teachers in enhancing their skills and performance through effective teacher training programs. The identification of the determinants of a positive interpersonal teacher student relationship could also serve as a springboard for future research in order to improve Saudis students' learning of EFL and subsequently their learning outcomes.

\subsection{The Current Study}

Therefore, taking into account the empirical recognition given to the critical nature the relationship between the student and the teacher, this research will investigate teachers' personality and profile as perceived by their students. Given the scarcity of research on this topic in Saudi Arabia, and especially concerning the learning of English as a foreign language, this study will focus on EFL students' perception of their teachers' interpersonal behaviour in Saudi Arabia. In addition to being a pioneering study on teacher-student interpersonal relationships in Saudi Arabia, this study is the first one to look into teacher interpersonal behaviour from the EFL students' perspective.

A key focus will be to consider if teacher dominance and competiveness are related to students' learning outcomes. For the purpose of this research a sample of 200 female secondary EFL students was selected from two schools in Eastern of Riyadh. To tap into the student participants' perception of their teachers' interpersonal behaviour, all the student participants completed the 'Teacher Interaction Questionnaire (QTI)'. The findings are mainly reported in terms of two independent dimensions: influence (teacher dominance vs. submission) and proximity (teacher cooperation vs. opposition).

\subsection{Research Questions}

To address the existing gap in knowledge in relation to teacher interpersonal behaviour in the Saudi EFL context, the research questions of the current study are the following:

1. What role does interpersonal teacher behaviour play in enhancing Saudi student outcomes in Saudi EFL classrooms?

2. In what ways/s does the teacher-student interpersonal relationship contribute towards the enhancement of the motivation of Saudi EFL learners?

3. To what extent does the teachers influence and proximity impact on student motivation and learning?

\section{Method}

\subsection{Design and Participants}

This was a cross-sectional study. A total of 200 students took part in this study. The participants were female EFL students from two secondary/high schools in Eastern Riyadh in Saudi Arabia. Participants' age varied between 16 and 18 years old $(\mathrm{M}=17.01)$. Each school provided access to 100 participants from three different classes (based on age) and each class was taught by an individual EFL teacher who had been teaching the group for at least 6 months. The study followed a purposive sampling method; it is a non-probability method based on which the sample was selected to serve the purpose of the study and their relevance (Mason, 2002). The researcher had access to three classes per school (16 years $=65$ participants; 17 years $=67$ participants: 18 years: 68 participants $)$ was used to select suitable respondents for this study. It should be noted that some questionnaires were not fully completed; however none of the questionnaire was dismissed.

\subsection{Measure: The Questionnaire on Teacher Interaction (QTI)}

The questionnaire used in this research consisted of an Arabic translation of the Questionnaire on Teacher Interaction (QTI). The questionnaire was then back translated; it was further assessed by a specialist in education and Arabic to ensure its content validity (it covers/answers the main research questions). The QTI is based upon a model for interpersonal behaviour from a systems perspective, adapted from theory on communication processes. According to the systems perspective the behaviour of participants play a mutually influential role on one another. Thus, the behaviour of the teacher is mediated by the students' behaviour and vice versa. The resulting circular communication process describes as well as determines behaviour. With this in mind, the model for interpersonal teacher behaviour (MITB) was mapped and from this the Questionnaire on Teacher Interaction (QTI) was created (Wubbels, Creton, \& Hooymayers, 1985; Wubbels, Brekelmens, \& Hooymayers, 1991). The original version of the QTI is 77-items long 
and has been found to be reliable and valid across a number of countries (E.g., Wubbels, Brekelmans, \& Hooymayers, 1991; Wubbels \& Levy, 1993). The questionnaire used here is an adapted version of the original QTI consisting of 14 items that specifically serve the main research questions. The questionnaire was then re-validated; it was shortened due to the limited time available for schools and because many of the questions do not serve the research purpose (See Appendix I).

The questions assess the EFL teacher's personality and skills as perceived by the students and ultimately the impact of this on the learning of Saudi Students. This perception is recorded via questions in the QTI which probe the students for their opinion by selecting the appropriate options which are related to their English teacher's personality and profile. Additionally, some questions are aimed to identifying students' motivation for participating in the English course, their competence level and their participation level during the class. They are also asked to rate the course structure and finally their preference is sought for Arabic usage during English class. The questionnaire is in the form of closed-ended multiple choice answers. Some of questions require a binary, yes, no or sometimes answer (e.g. Do you think that your EFL teacher is a good leader?). Other remaining questions require that the answer be chosen from a possible list of answers (e.g., What is the motivation for you to study English? Available options: Further education / Enhance knowledge/ Travel/ Interesting / Other Please State).

\subsection{Procedure}

Informed consent for the voluntary participation was obtained from participants and participants using consent letter that were sent out by the school. The researcher guaranteed confidentiality and anonymity for all participants and they were assured that they were able to withdraw from the study at any point or and could refuse to answer any question. The students were asked to fill questionnaires which investigated their perception of their English as a foreign language teachers' interpersonal behaviour. Each class was approached separately; the researcher introduced herself and explained the purpose of the study and that the questionnaire would take approximately 10 minutes. Prior to starting the questionnaire each participant was asked to read the instructions and sign their consent form. Following their participation the researcher invited questions or any concerns by students. All participants had been taught by their EFL teacher for at least 6 months. Students were further assured that their EFL teacher will not have access to the data neither will the school. Contact details were provided for further questions, participation in each of the two schools was finished within a day.

\section{Results}

The results of the study are concerned with two main aspects as revealed by the student questionnaire. The first aspect relates to the individual attributes of teacher as rated by the students. The second aspect is concerned with the students' opinion of their own motivation (for learning this course), competence level, and participation level/behaviour. The interaction between these two aspects (teacher's personality and profile as reported by the student and the students' motivation, competency and behaviour) is also reported here.

\subsection{Teacher Personality and Profile}

This section provides the results from question 1 to 7 and questions 12 and 14 from the questionnaire, which deals with the personality of teacher as rated by the students. The number of participants answering 'yes, no or sometimes' to the individual questions are shown in table 1 . The results show that more than $70 \%$ of students agreed that their teacher was a good leader and that they could rely on him/her. More than $85 \%$ of the students were of the opinion that their teacher listens to them when they say or ask about something in class, and the teacher takes time to give them help. Almost $80 \%$ of students reject the opinion that their teacher showed any uncertainty in class. More than $78 \%$ of students say their teacher is not strict. Nearly $75 \%$ of students said that their teachers do not get angry often.

The participants' were asked to describe their perceptions of their teacher's profile. Participants described their teachers' personality profiles as: $26.56 \%(\mathrm{~N}=47)$ directive; $2.26 \%(\mathrm{~N}=4)$ authoritative; $7.91 \%(\mathrm{~N}=14)$ tolerant and authoritative; 49.72\% ( $\mathrm{N}=88)$ tolerant; $12.99 \%(\mathrm{~N}=23)$ Uncertain/tolerant and $0.56 \%(\mathrm{~N}=1)$ Uncertain/aggressive (total $\mathrm{N}=177$ ). 
Table 1. Students' perception of teacher's personality and profile

\begin{tabular}{lcccc}
\hline & $\begin{array}{c}\text { Yes } \\
\mathrm{N}(\%)\end{array}$ & $\begin{array}{c}\text { No } \\
\mathrm{N}(\%)\end{array}$ & $\begin{array}{c}\text { Sometimes } \\
\mathrm{N}(\%)\end{array}$ & $\begin{array}{c}\text { Total } \\
(\mathrm{N})\end{array}$ \\
\hline $\begin{array}{l}\text { Do you think that your EFL teacher is a good leader? } \\
\text { Is the teacher helpful/friendly and can you depend on }\end{array}$ & $140(77.3)$ & $41(22.7)$ & & 181 \\
her? & & $8(4.4)$ & $48(26.2)$ & 183 \\
$\begin{array}{l}\text { Does you teacher listen to you when you have } \\
\text { something to say in class or ask about something? }\end{array}$ & $168(92.3)$ & $12(6.6)$ & $2(1.1)$ & 182 \\
$\begin{array}{l}\text { Does your teacher give you time in class? } \\
\text { Does your teacher seem to be uncertain at times? }\end{array}$ & $152(85.4)$ & $26(14.6)$ & & 178 \\
Is your teacher strict? & $35(19.6)$ & $143(79.9)$ & $1(0.6)$ & 179 \\
Does your teacher get angry often? & $47(25.8)$ & $141(78.3)$ & $2(1.1)$ & 184 \\
Are the English lessons well organised and structured & $90(50.3)$ & $89(74.2)$ & & 182 \\
\hline
\end{tabular}

As shown in table 1, the number of student participants answering 'yes, no or sometimes' to the individual questions about personality and interpersonal profile of the teacher, as perceived by the teacher.

\subsection{Students' motivation, competency and behaviour}

This section covers up the results for the questions related to students' motivation, competence level, participation level and behaviour in class. These question range from question no. 8 to 12 . When asked "What is the motivation for you to study English?" $30.7 \%$ ( $=55)$ selected 'Higher education" as the answer; $29.6 \%(\mathrm{~N}=53)$ chose "Enhance knowledge, $15.1 \%(\mathrm{~N}=27)$ chose 'travel'; $23.5 \%(\mathrm{~N}=42)$ 'Just interesting'; and 1.1\% $(\mathrm{N}=2)$ selected 'other' (total $\mathrm{N}$ $=179$ ).

In answer to "Which of the following best describes your behaviour in EFL class" 65.7\% (N=117) selected 'I am willing to participate in English Lessons'; 19.1 ( $\mathrm{N}=34$ ) selected 'I do not voluntary participate in English lessons'; $10.7 \%(\mathrm{~N}=19)$ chose 'I voluntary speak during English lessons'; 4.5\% $(\mathrm{N}=8)$ 'I am not willing to participate in English lessons' (total $\mathrm{N}=178$ ). When asked to "describe [their] competence level in English" 31.8\% ( $\mathrm{N}=57$ ) answered 'good'; 22.3\% ( $\mathrm{N}=40)$ 'bad'; $12.8 \%(\mathrm{~N}=23)$ 'Capable of working hard' and 33\% ( $=59)$ answered 'Understand what is being taught' (total $\mathrm{N}=179$ ). In answer to the question "do you work cooperatively with classmates during English Lessons?" 15.6\% $(\mathrm{N}=28)$ answered no, 83.9\% $(\mathrm{N}=151)$ answered yes; and 0.6\% $(\mathrm{N}=1)$ answered sometimes (total $\mathrm{N}=180$ ). In answer to "do you prefer the teacher to use Arabic in English Classes?" $36.8 \%$ $(\mathrm{N}=70)$ selected no; $52.6 \%(\mathrm{~N}=100)$ yes; and $10.6 \%(\mathrm{~N}=20)$ participants choose sometimes (total $\mathrm{N}=190)$.

\subsection{Interaction between Teacher's Personality Profile and Students' Motivation, Competency and Behaviour}

The interaction between these the teacher's personality and profile as reported by the student and the students' motivation, competency and behaviour was examined. Table 2 shows the observed pattern of frequency between the students' answers to the question "How would you describe your competence level in English?" and the question "Please describe from the following your perceptions of your teacher's profile?"

Table 2. Students' competency levels and ratings of teacher's profile

\begin{tabular}{|c|c|c|c|c|c|}
\hline & Good & $\mathrm{Bad}$ & $\begin{array}{c}\text { Capable of } \\
\text { working hard }\end{array}$ & $\begin{array}{l}\text { Understand what is } \\
\text { being taught }\end{array}$ & $\begin{array}{l}\text { Total } \\
(\mathrm{N})\end{array}$ \\
\hline Directive & 15 & 6 & 10 & 16 & 47 \\
\hline Authoritative & 0 & 1 & 3 & 0 & 4 \\
\hline $\begin{array}{l}\text { Tolerant } \\
\text { authoritative }\end{array}$ & 5 & 6 & 0 & 3 & 14 \\
\hline Tolerant & 28 & 19 & 5 & 36 & 88 \\
\hline Uncertain/tolerant & 8 & 7 & 5 & 3 & 23 \\
\hline Uncertain/aggressive & 1 & 0 & 0 & 0 & 1 \\
\hline Total & 57 & 39 & 23 & 58 & 177 \\
\hline
\end{tabular}

As shown in table 2, the observed pattern of frequency for students with different self-rated competency levels and how they rated their teacher's profile.

The results to the Chi square test was significant indicating a relationship between teacher profile and student 
competence, $\chi^{2}(15,177)=36.35, p<0.01$.

Table 3. Students' participation levels and teacher anger levels

\begin{tabular}{lccccc}
\hline & $\begin{array}{c}\text { I am willing to } \\
\text { participate in } \\
\text { English Lessons }\end{array}$ & $\begin{array}{c}\text { I do not voluntary } \\
\text { participate in } \\
\text { English lessons }\end{array}$ & $\begin{array}{c}\text { I voluntary } \\
\text { speak during } \\
\text { English lessons }\end{array}$ & $\begin{array}{c}\text { I am not willing } \\
\text { to participate in } \\
\text { English lessons }\end{array}$ & $\begin{array}{c}\text { Total } \\
(\mathrm{N})\end{array}$ \\
\hline Yes -often angry & 87 & 26 & 14 & 5 & 132 \\
No- not often angry & 30 & 7 & 5 & 3 & 45 \\
Total & 117 & 33 & 19 & 8 & 177 \\
\hline
\end{tabular}

As shown in Table 3, the observed pattern of frequency between the students' answers to the question "Does your teacher get angry often?" and the question "Which one of the following best describes your behaviour in EFL classes?"

The results to the Chi square test was not significant indicating no relationship between perceived frequency of anger of teacher profile and self- rated willingness of students to participate in their English lessons, $\chi^{2}(3,177)=0.94$, $\mathrm{p}>0.05$.

Table 4. Students' competency levels and lesson structure

\begin{tabular}{lccccc}
\hline & Good & Bad & $\begin{array}{c}\text { Capable of } \\
\text { working hard }\end{array}$ & $\begin{array}{c}\text { Understand what } \\
\text { is being taught }\end{array}$ & $\begin{array}{c}\text { Total } \\
(\mathrm{N})\end{array}$ \\
\hline $\begin{array}{l}\text { No - the lessons are not } \\
\text { well structured }\end{array}$ & 24 & 25 & 13 & 27 & 24 \\
$\begin{array}{l}\text { Yes - the lessons are } \\
\text { well structured }\end{array}$ & 33 & 15 & 10 & 32 & 33 \\
Total & 57 & 40 & 23 & 59 & 57 \\
\hline
\end{tabular}

As shown in table 4, the observed pattern of frequency for students with different self-rated competency levels and whether they rated their lessons as being well-structured.

The results to the Chi square test was not significant therefore it can be concluded that both attributes are independent i.e. course structure do not affect student's competency level in English or vice versa, $\chi^{2}(3,179)=4.73$, $\mathrm{p}>0.05$.

\section{Discussion}

This research was undertaken with the aim of investigating the attributes of EFL teachers in Saudi Arabia as well as the students' opinion of their own motivation, their perceived competence level, participation level and behaviour. This research was also concerned with the interaction between these two aspects (teacher's personality and profile as reported by the student and the students' motivation, competency and behaviour).

In terms of the students' opinion of their teacher, the results are generally positive. More than $70 \%$ of students agreed that their teacher was a good leader and that their teacher could be relied on and $85 \%$ believed that their teacher listened to them and gave time to help them. Almost $80 \%$ of students did not hold the opinion that their teacher showed any uncertainty in class. Over $78 \%$ of students said their teacher was not strict and nearly $75 \%$ of students said that their teacher did not get angry often. These results are key findings, since teacher-student interpersonal behaviour is a crucial factor for the success of learning. Since this effect has been shown to be valid across cultures, it can be safely assumed that a positive teacher-student interpersonal relationship between teachers and EFL students in Saudi Arabia will improve the learning experience, and learning outcomes. However, although these results are generally positive there is clearly room for improvement. In an ideal classroom, it could be expected that close to $100 \%$ of students would classify their teacher as someone to be relied on, as good leader and as someone who did not get angry often.

Other aspects of teaching were revealed to be in greater need of improvement. For example, whilst half of students asserted that the English classes were well structured, the other half of students disagreed. This is a disappointing result, especially considering that it has been previously argued that Saudi EFL learners appear to possess a considerable amount of an in-built 'dormant' store of motivation and that favourable conditions, this could be 
successfully exploited to enrich academic achievement (Moskovsky \& Alrabai, 2009). It has also been stressed in the Saudi EFL learners are in need of teaching strategies that boost their motivation levels (Rao, 2005). More effective teaching strategies are needed in order to fully take advantage of the students' keenness for learning English. Although disheartening, this result is not unexpected. It has previously been reported that EFL teacher preparation programs in Saudi Arabia are non-systematic and do not meet the needs of the student teachers Al Hazmi (2003). In addition, the great demand for learning English means that teachers that are untrained often end up teaching English as a second language in order to keep up with demand. This results in a poorer quality of both teaching and learning. This is clearly an issue that needs addressing.

The specific reasons why the students in this study were motivated to study English were varied. Reasons included higher education, enhancement of knowledge, and travel. An effective teaching policy could utilise these varied reasons to provide a variety of learning activities reflecting these interests, since research has shown motivation to play a determining role in second language acquisition (Moskovsky \& Alrabai, 2009). Interacting with the students in a way that emphasises these varied reasons may be key in engaging the students more effectively and increasing motivation.

It was also found that a large number of students (around one third) were unwilling to participate in class. This lack of socialisation in class undermines the learning of Saudi students. One way of improving this is for teachers to display a higher level of interpersonal closeness. This in turn increases the likelihood of the students feeling that they are being treated fairly, and hence students are more likely to take participate in class. Student- centeredness and activating instructions have also been emphasised as being key in active student learning (Brekelmans, Sleegers, \& Fraser, 2000).

It has previously been found that directive-authoritative-tolerant and tolerant-authoritative teacher types are the most frequently observed teacher student interactions. These types of interactions result from an activity based learning environment that is positively related with students' engagement, motivation and outcomes (Opdenakker et al., 2012). The most common teacher profile reported in this study was either tolerant or directive, rather than being the more preferential mixture of the two. The competency level of the student participants was found to be significantly influenced by the personality profile of the teacher. This reveals evidence of a systematic problem in EFL teacher preparation program that undermines the English Language learning in Saudi. Interestingly, the same effect was not seen with the teacher's perceived anger or the course structure. It was established that these two latter factors do not affect student's competency level in English and vice versa. This result highlights the importance of teacher proximity as a key focus for future work in improving Saudi EFL learner outcomes.

Teachers' behaviours have a direct impact on students and that is why various authors have highlighted the significance of interpersonal relationships for student learning in classroom. The student teacher interactions are a continual transaction and this transactional process shapes the interpersonal behaviour of the students and teachers. The findings of this study, taken together with the findings of other international studies, can be used as a practical framework for studying interpersonal student teacher relationship in Saudi Arabia and assessing how the teachers can effectively engage their students. More than a fifth of students, considered themselves by their own admission as being 'bad' at English. It is therefore clear that improvement needs to be made. In Saudi EFL classrooms the students are reluctant to share their ideas with their teachers and discuss any problems with them. Based on this study the teachers could take a more proactive role and encourage students to communicate openly with the teachers. The literature on interpersonal relationships suggests that the teachers must initiate communications, show respect and build mutual understanding in the classroom. In the Saudi context the teachers must be able to take into account the Saudi culture and student motivations. By connecting to the students, the students can become more motivated and better student outcomes can be achieved.

Future research must focus on the specifics of a positive teacher-student interpersonal relationship. The identification of the determinants of a positive interpersonal teacher student relationship could also serve as a springboard for future research in order to improve Saudis students' learning of EFL and subsequently their learning outcomes. Research has shown a clear link between teacher characteristics such as dominance and cooperativeness and students' affective outcomes such as effort, pleasure, relevance, confidence and (e.g., den Brok, 2001; den Brok et al., 2004; den Brok, Fisher, \& Scott, 2005; Kim, Fisher, \& Fraser, 2000; Riah \& Fraser, 1998). However, the association between students' achievement and their perception of teacher behaviour is concerned; results have been less clear-cut. This current study found a link between perceived teacher profile and student self-rated competency in English. This could be further explored in future studies that might take a longitudinal approach, examining student outcomes before and after time spent with specific EFL teachers. Additionally, lack of EFL teachers in Saudi Arabia 
has resulted in the Ministry of Education in recruiting non-Saudi English teachers to meet the high demand for EFL courses (Al Hazmi, 2003). This is an aspect that might be explored in future research - what effect does being taught by a non-native have on student learners compared with being taught by native teachers, if any.

The findings in this study are pioneering, considering that this is the first study in Saudi Arabia EFL students' perception of their teachers' interpersonal behaviour. One of the limitations of this is the small sample size. A further limitation is the focus on female students only. Future studies could address this by using a mixed sample including male and female participants. This is of key note, since some studies have found differences in males and females and how they perceive their teacher (e.g. Levy, den Brok, Wubbels, \& Brekelmans, 2003). Future studies might also employ a larger sample group, and use other methods in addition to the QTI in order to obtain a broader view of teacher-student interactions, affective and cognitive outcomes.

The teachers in Saudi EFL classrooms should show connectedness with students by developing personal knowledge of the students and showing a genuine care of the students. Also Saudi EFL teachers must show a supportive attitude towards students in order to encourage better performance and should be available for communication with the student at all times and deal with students both in as individuals as well as in groups. Spending time with the students must be a priority and the teacher must be able to follow up with the students regarding their academic, social or emotional concerns. The EFL teacher in Saudi Arabia should encourage effective teamwork by communicating and relating effectively. Such teamwork in EFL classes can create empathy and respect for other views and provide an opportunity for accurate self-evaluation of performance. The Saudi EFL teacher must encourage active listening; provide direct feedback with a focus on nonverbal communications.

\section{Acknowledgements}

I would like to express my gratitude to Dr. Rafik Ahmad for his patience, guidance, enthusiasm, encouragement in this research. Thanks are also extended to Dr. Azmi Adel and Dr. Zuhair Zaghloul; their valuable feedback and encouragement are greatly appreciated. I wish to thank my parents and my parents-in-low for their support and encouragement throughout my study. Finally, I would like to express my deep gratitude to my husband Yasser AlZunidy for his cherished support that has been a source of motivation for me.

\section{References}

Aleamoni, L. M. (1999). Student rating myths versus research facts from 1924 to 1998. Journal of Personnel Evaluation in Education, 13, 153-166. http://dx.doi.org/10.1023/A\%3A1008168421283

Al Hazmi, S. (2003). EFL teacher preparation programs in Saudi Arabia: Trends and challenges. TESOL Quarterly, 37(2), 341-344. http://dx.doi.org/10.2307/3588509

Birch, S. H., \& Ladd, G. W. (1998). Children's interpersonal behaviors and the teacher-child relationship. Developmental psychology, 34(5), 934. http://dx.doi.org/10.1037/0012-1649.34.5.934

Brekelmans, M., Brok, P.den, Tartwijk, J. van, \& Wubbels, T. (2005). An interpersonal perspective on teacher behaviour in the classroom. In L. V. Barnes (ed.), Contemporary Teaching and Teacher Issues (pp. 197-226). New York: Nova Science Publishers.

Brekelmans, M., Sleegers, P., \& Fraser, B. (2000). Teaching for active learning. In New learning (pp. 227-242). Springer Netherlands.

Brekelmans, M., Wubbels, Th., \& Créton, H. A. (1990). A study of student perceptions of physics teacher behaviour. Journal of Research in Science Teaching, 27, 335-350. http://dx.doi.org/10.1002/tea.3660270405

Brok, P. den (2001). Teaching and student outcomes. Utrecht: W. C. C.

Brok, P. den, Fisher, D., \& Scott, R. (2005). The importance of teacher interpersonal behaviour for student attitudes in Brunei primary sciences classes. International Journal of Science Education, 27(3), 765-779. http://dx.doi.org/10.1002/tea.3660270405

Crosnoe, R., Johnson, M. K., \& Elder, G. H. (2004). Intergenerational bonding in school: The behavioral and contextual correlates of student-teacher relationships. Sociology of Education, 77(1), 60-81. http://dx.doi.org/10.1177/003804070407700103

Fisher, D., Waldrip, B., \& den Brok, P. (2005). Students' perceptions of primary teachers' interpersonal behaviour 
and of cultural dimensions in the classroom environment. International Journal of Educational Research, 43(1-2), 25-38. http://dx.doi.org/10.1016/j.ijer.2006.03.004

Fraser B. J., \& Walberg H. J. (2005). Research on teacher-student relationships and learning environments: Context, retrospect and prospect. International Journals of Educational Research, 43(1-2), 103-109. http://dx.doi.org/10.1016/j.ijer.2006.03.001

Greenwald, A. G. (1997). Validity concerns and usefulness of student ratings of instruction. American Psychologist, 52(11), 1182. http://dx.doi.org/10.1037/0003-066X.52.11.1182

Goh, S. C., \& Fraser, B. J. (1998). Teacher interpersonal behaviour, classroom environment and student outcomes in primary mathematics classes in Singapore. Learning Environments Research, 1, 199-229. http://dx.doi.org/10.1023/A:1009910017400

Gorgen, Z., \& Tahta, H. (2005). A comparison of teacher attitudes and students expectations in the process of mathematics instruction in secondary education [In Turkish]. Milli Egitim Dergisi, 166, 1-55. http://dx.doi.org/10.1007/s10984-007-9023-2

Henderson, D. G. (1995). A study of the classroom and laboratory environments and student attitude and achievement in senior Secondary Biology classes. Unpublished doctoral dissertation. Perth: Curtin University of Technology.

Kiany G. R., \& Shayestefar, P. (2011). High school students' perceptions of EFL teacher control orientations and their English academic achievement. British Journal of Educational Psychology, 81, 491-50.

Kim, H., Fisher, D., \& Fraser, B. (2000). Classroom environment and teacher interpersonal behaviour in secondary science classes in Korea. Evaluation and Research in Education, 14, 3-22. http://dx.doi.org/10.1080/09500790008666958

Levy, J., den Brok, P., Wubbels, T., \& Brekelmans, M. (2003). Students' perceptions of interpersonal aspects of the learning environment. Learning Environments Research, 6(1), 5-36. http://dx.doi.org/10.1023/A\%3A1022967927037

Moskovsky, C., \& Alrabai, F. (2009). Intrinsic motivation in Saudi learners of English as a foreign language. Open Applied Linguistics Journal, 2, 1-10. http://dx.doi.org/10.2174/1874913500902010001

Opdenakker, M. C., Maulana, R., \& den Brok, P. (2012). Teacher-student interpersonal relationships and academic motivation within one school year: Developmental changes and linkage. School Effectiveness and School Improvement, 23(1), 95-119. http://dx.doi.org/10.1080/09243453.2011.619198

Rao K. Faculty and student motivation: KFUPM faculty perspectives [serial online] 2005 [cited 2006 Dec 04]; Retrieved from http://www.kfupm.edu.sa/dad/richfiles/pdf/06krishnarao.pdf - I can not find this paper online.

Riah, H., \& Fraser, B. J. (1998). The learning environment of high school chemistry classes. Paper presented at the annual meeting of the American Educational Research Association, San Diego.

Rawnsley, D. G. (1997). Associations between classroom learning environments, teacher interpersonal behaviour and student outcomes in secondary Mathematics classrooms. Unpublished doctoral dissertation. Perth: Curtin University of Technology.

Robson, C. (2002). Real word research. Oxford: Blackwell.

Rowan, B., Chiang, F. S., \& Miller, R. J. (1997). Using research on employees' performance to study the effects of teachers on students' achievement. Sociology of Education, 256-284.

Shulman, L. S., \& Tamir, P. (1972). Research on teaching in the natural sciences. In Travers R. M. W. (Ed.), Second handbook of research on teaching (pp. 1098-1148). Chicago: Rand McNally.

Telli, S., den Brok, P., \& Cakiroglu, J. (2007). Students' perceptions of science teachers' interpersonal behaviour in secondary schools: Development of a Turkish version of the Questionnaire on Teacher Interaction. Learning Environments Research, 10(2), 115-129. http://dx.doi.org/10.1007/s10984-007-9023-2

Wei, M., den Brok, P., \& Zhou, Y. (2009). Teacher interpersonal behaviour and student achievement in English as a Foreign Language classrooms in China. Learning Environments Research, 12(3), 157-174. http://dx.doi.org/10.1007/s10984-009-9059-6

Yu T. M., \& Zhu, C. (2011). Relationship between teachers' preferred teacher-student interpersonal behaviour and intellectual styles. An International Journal of Experimental Educational Psychology, 31(3), 301-31. 